\title{
Perancangan Ulang Tata Letak Fasilitas Industri Sandal dengan Metode CORELAP
}

\author{
(Redesign of the Layout of Slippers Industrial Facilities using the CORELAP Method) \\ Muhammad Faishal ${ }^{a}$, Muhammad Khrisna Putra ${ }^{\mathrm{b}}$ \\ a,b TeknikIndustri, Fakultas Teknologi Industri, Universitas Ahmad Dahlan \\ Jl. Ringroad Selatan, Tamanan, Kec. Banguntapan, Bantul, D.I Yogyakarta 55191 \\ Telephone: (0274) 511830 \\ e-mail: muhammad.faishal@ie.uad.ac.id
}

\begin{abstract}
Abstrak
Tata letak pabrik yang baik dapat menempatkan berbagai fasilitas dan peralatan fisik secara teratur sehingga mendukung pekerjaan berjalan secara produktif. Penelitian ini dilakukan di perusahaan yang memproduksi sandal spon sebagai fasilitas di penginapan. Perusahaan ini memiliki masalah yaitu pemborosan pada aliran material di beberapa area yang seharusnya tidak diperlukan seperti dari gudang ke proses pengeleman yang berjarak $\pm 50 \mathrm{~m}$. Selain itu, masih terdapat lintasan yang bersimpangan seperti pada penjahitan cup ke penjahitan sol. Penelitian ini bertujuan membuat tata letak fasilitas baru yang tepat dan baik untuk mengurangi pemborosan jarak material handling yang terjadi. Metode yang digunakan dalam penelitian ini menggunakan Computerized Relationship Layout Planning (CORELAP). Dengan membuat 5 layout alternative dengan nilai (score) berbeda. Layout yang akan dipilih dengan score terkecil. Metode CORELAP merupakan metode construction yang mengubah data kualitatif menjadi data kuantitatif sehingga menentukan fasilitas pertama yang diletakkan di dalam layout dan menggunakan pendekatan data keterkaitan hubungan aktivitas. Hasil penelitian ini adalah didapatkan usulan tata letak fasilitas dengan CORELAP alternatif terpilih yang mengoptimalkan perubahan 9 departemen sehingga mendapatkan pegurangan jarak total sebesar $46 \%$, atau dari jarak $273.5 \mathrm{~m}$ menjadi $125.8 \mathrm{~m}$.
\end{abstract}

Kata kunci: Tata Letak Fasilitas, CORELAP, Pemborosan, Material Handling

\begin{abstract}
A good layout can place various facilities and physical equipment on a regular basis so as to support the work running productively. This research was conducted at a company that manufactures sponge slippers as a facility at the inn. This company has a problem that is waste in the flow of material in some areas that should not be needed such as from the warehouse to the gluing process is within $\pm 50 \mathrm{~m}$. in addition, there are still crossing trajectories such as cup sewing to sol sewing. This study aims to create a new facility layout that is appropriate and good to reduce the waste of material handling distance that occurs. The method used in this study uses Computerized Relationship Layout Planning (CORELAP). By making 5 alternative layouts with different score values. The layout with the smallest score will be chosen. CORELAP method is a construction method that converts qualitative data into quantitative data. Therefore, we determine the first facility that is placed in the layout, using the data approach to the relationship between activities. The results of this study is to get a proposed layout of facilities with a selective alternative CORELAP that optimizes by changing 9 departments so as to get a reduction in total distance of $46 \%$, or from $273.5 \mathrm{~m}$ to $125.8 \mathrm{~m}$.
\end{abstract}

Keywords: Facility Layout, CORELAP, Waste, Material Handling 


\section{Pendahuluan}

Dalam rangka meningkatkan produktivitas, perusahaan memiliki banyak cara, tetapi cara yang umum dilakukan adalah perancangan tata letak fasilitas perusahaan[1]. Tata letak yang baik dari segala fasilitas produksi dalam suatu pabrik yaitu yang mampu membuat operasi kerja menjadi lebih efektif dan efisien serta menjaga kesuksesan kerja suatu industri [1]. Perusahaan $X Y Z$ adalah salah satu perusahaan sandal di Yogyakarta. Saat ini, sandal yang diproduksi mencapai 10 ribu pasang per hari dengan mempekerjakan 20 orang. Terdapat 2 jenis sandal spon yang diproduksi pada perusahaan ini, yaitu sandal hotel dan sandal souvenir. Proses produksi pembuatan sandal souvenir dapat dilihat pada Gambar 1.1. Skema alur produksi tersebut dapat mewakili jenis proses produksi sandal hotel dengn mempertimbangkan rangkaian proses yang memiliki produk tambahan.

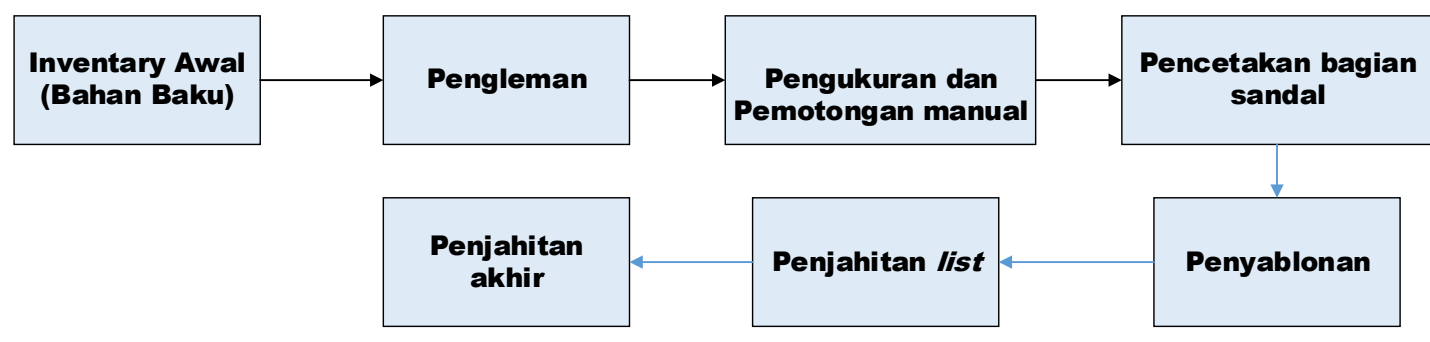

Gambar 1.1. Aliran produksi sandal

Bangunan perusahaan ini memiliki ukuran tidak terlalu luas dengan penambahan bangunan semipermanen di sekitarnya. Perusahaan ini berkembang cukup pesat. Perkembangan tersebut didasarkan pada jumlah permintaan sandal spon dari konsumen yang terus meningkat. Akan tetapi, perusahaan ini memiliki permasalahan pada aliran material yang menyebabkan produksi sandal belum maksimal. Tata letak fasiltas di perusahaan sandal ini dalam penentuan kebutuhan ruangan tidak memperhatikan aliran proses produksi, terdapat aliran balik dan lintasan yang bersimpangan, dan penempatan setiap departemen hanya sesuai kebutuhan. Berdasarkan pengamatan di lapangan dan wawancara yang telah dilakukan, dapat disimpulkan bahwa aktivitas produksi sandal spon menyebabkan jarak material handling menjadi besar. Waste yang terjadi berpotensi merugikan waktu dan biaya produksi.

Beberapa penelitian terdahulu sudah dilakukan terkait perancangan tata letak fasilitas (TLF) perusahaan, Faishal, dkk. merancang ulang TLF perusahaan sandal juga dengan metode ARC dan mampu meningkatkan produksi sebesar 4,19\% dan menghemat waktu perpindahan sebesar 26,52\% [2]. Budiono, Dwianto dkk., dan Langgihadi melakukan penelitian perancangan tata letak fasilitas dengan menggunakan metode CORELAP dan mampu meningkatkan utilisasi area perusahaan [3], [4] dan [5]. Faishal dkk merancang ulang fasilitas perusahaan untuk mengurangi waste perusahaan [6]. Perancangan perusahaan dengan metode CORELAP juga dilakukan oleh Ardyan dkk. untuk meminimalisasi material handling [7]. P.W.J dan Shayan melakukan perancangan dengan lini produksi furnitur menggunakan metode formal [8]. Y.P Putra merancang tata letak fasilitas pabrik dengan metode algoritma CORELAP dan mampu menghemat jarak material handling sebesar 49\% [9]. Siregar, dkk. berhasil melakukan perancangan ulang tata letak fasilitas produksi dengan menerapkan algoritma blocplan dan algoritma CORELAP untuk meningkatkan efisiensi perpindahan material [10]. N.H Prasad dkk. melakukan perbaikan layout dengan metode CRAFT untuk mengurangi biaya perusahaan [11]. Rubianto dan Bendatu melakukan penentuan lokasi dan perancangan tata letak fasilitas tempat packaging PT $A B C$ dengan membandingkan tiga metode dengan hasil terbaik dengan metode CORELAP [12]. Oleh karena itu, penelitian ini melakukan perancangan ulang tata letak fasilitas dengan menggunakan metode CORELAP untuk mengurangi waste aliran proses. 


\section{Metode Penelitian}

Tujuan penelitian ini adalah merancang ulang tata letak fasilitas perusahaan sandal untuk mendapatkan layout dengan jarak yang lebih pendek. Adapun metodologi yang dilakukan untuk mencapai tujuan adalah sebagai berikut:

\section{a. Observasi Awal}

Tahapan ini dilakukan untuk melihat kondisi sesungguhnya di lapangan dengan metode genba langsung untuk melihat kondisi yang sebenarnya. Selain itu, dilakukan juga kajian literasi terkait dengan penelitian yang akan dilakukan.

\section{b. Pengumpulan Data Awal}

Data awal yang dikumpulkan adalah ukuran layout awal, profil dan organisasi perusahaan, jenis dan ukuran mesin, frekuensi perpindahan material, dan data proses produksi.

\section{c. Pengolahan Data}

Pengolahan data yang dilakukan adalah pembuatan Activity Relationship Chart, menghitung rating kedekatan, pengalokasian fasilitas dan perhitungan jarak, dan biaya material handling.

\section{Hasil dan Pembahasan}

Perusahaan sandal ini bertempat di kota Yogyakarta yang merupakan perusahaan yang bergerak di bidang manufaktur dengan mengutamakan desain dan kualitasnya.

\subsection{Informasi layout awal}

Layout awal perusahaan sandal ini dapat dilihat pada Gambar 3.1, adapun ukuran area masing-masing fasilitas terdapat dalam Tabel 3.1.

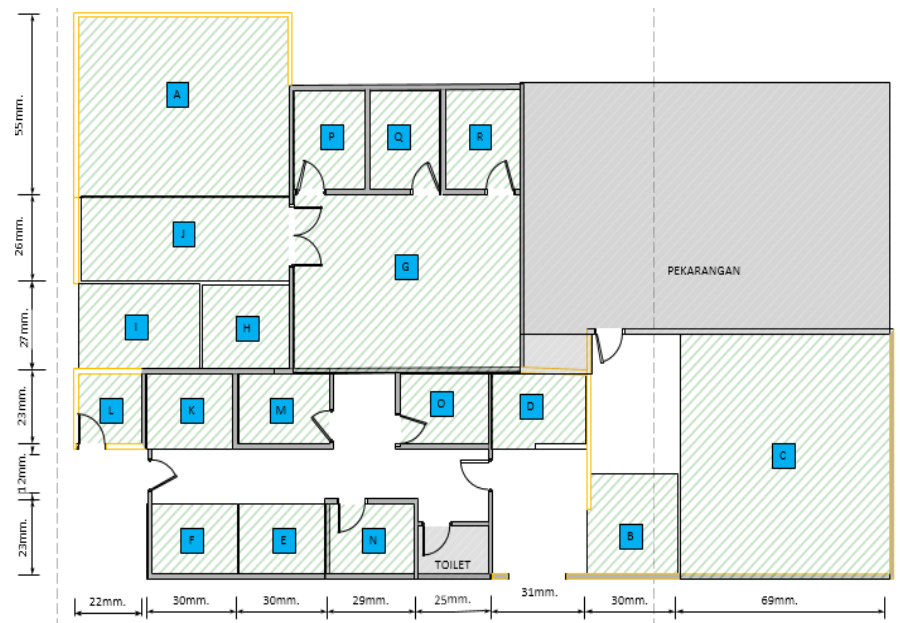

Gambar 3.1. Layout awal

Tabel 3.1. Ukuran awal fasilitas

\begin{tabular}{cllll}
\hline Kode & \multicolumn{1}{c}{ Fasilitas } & $\begin{array}{c}\text { Panjang } \\
(\mathbf{m})\end{array}$ & $\begin{array}{c}\text { Lebar } \\
(\mathbf{m})\end{array}$ & $\begin{array}{c}\text { Luas } \\
\left(\mathbf{m}^{\mathbf{2}}\right)\end{array}$ \\
\hline A & Gudang Spon & 7 & 5,5 & 38,5 \\
B & Pengeleman & 3 & 3,2 & 9,6 \\
C & Pengukuran \& pemotongan spon & 6,90 & 7,5 & 51,75 \\
D & Penyablonan & 3,10 & 2,3 & 7,13 \\
E & Penjahitan cup & 3 & 2,3 & 6,9 \\
F & Penjahitan sol 1 & 3 & 2,3 & 6,9 \\
G & Penjahitan sol 2 & 7,20 & 5,3 & 38,16 \\
H & Gudang kain & 3 & 2,7 & 8,1 \\
\hline
\end{tabular}




\begin{tabular}{|c|c|c|c|c|}
\hline Kode & Fasilitas & $\begin{array}{l}\text { Panjang } \\
\text { (m) }\end{array}$ & $\begin{array}{c}\text { Lebar } \\
\text { (m) }\end{array}$ & $\begin{array}{l}\text { Luas } \\
\left(m^{2}\right)\end{array}$ \\
\hline $\mathrm{I}$ & Area parkir & 4 & 2,7 & 10,8 \\
\hline $\mathrm{J}$ & Gudang produk jadi & 7 & 2,6 & 18,2 \\
\hline $\mathrm{K}$ & Kantor & 3 & 2,3 & 6,9 \\
\hline $\mathrm{L}$ & Kamar 1 & 2,20 & 2,3 & 5,06 \\
\hline $\bar{M}$ & Kamar 2 & 3 & 2,3 & 6,9 \\
\hline $\mathrm{N}$ & Kamar 3 & 2,9 & 2,3 & 6,67 \\
\hline 0 & Kamar 4 & 2,7 & 2,3 & 6,21 \\
\hline$P$ & Kamar 5 & 2,4 & 3 & 7,2 \\
\hline Q & Kamar 6 & 2,4 & 3 & 7,2 \\
\hline $\mathrm{R}$ & Kamar 7 & 2,4 & 3 & 7,2 \\
\hline & & & & 249.38 \\
\hline
\end{tabular}

\subsection{Diagram Alir}

Diagram alir proses produksi dalam membuat sandal souvenir dan hotel ditunjukkan pada Tabel 3.2. dengan jarak total antardepartemen dihitung dari titik pusat setiap fasilitas.

Tabel 3.2. Aliran proses produksi

\begin{tabular}{ccccc}
\hline \multicolumn{2}{c}{ Sandal Hotel } & \multicolumn{2}{c}{ Sandal Sovenir } & \multirow{2}{*}{ Jarak (m) } \\
\cline { 1 - 4 } Dari & Ke & Dari & Ke & \\
\cline { 1 - 3 }- & - & A & B & 44 \\
A & C & - & - & 51 \\
- & - & H & B & 39 \\
- & - & B & C & 7,5 \\
C & D & C & D & 15,5 \\
C & F & C & F & 25 \\
C & G & C & G & 19,5 \\
D & E & D & E & 12 \\
E & F & E & F & 12 \\
E & G & E & G & 29 \\
F & J & F & J & 20 \\
G & J & G & J & 8 \\
& & & total & $\mathbf{2 7 3 , 5}$ \\
\hline
\end{tabular}

\subsection{Pembuatan ARC}

Activity Relationship Chart (ARC) digunakan untuk menunjukkan hubungan keterkaitan antardepartemen pada perusahaan yang nantinya digunakan untuk merancang perbaikan tata letak fasilitas berdasarkan derajat hubungan kedekatan. Dalam penelitian ini, alasan kedekatan antarfasilitas diperoleh berdasarkan pengamatan di lapangan dan wawancara langsung dengan pemilik usaha, seperti dalam Tabel 3.3.

Tabel 3.3. Alasan deskripsi kedekatan

\begin{tabular}{cl}
\hline Kode alasan & \multicolumn{1}{c}{ Deskripsi alasan } \\
\hline 1 & Urutan aliran bahan \\
2 & Derajat kontak personel yang sering dilakukan \\
3 & Kemungkinan mengganggu konsentrasi kerja \\
4 & Tenaga kerja yang sama \\
5 & Menggunakan area kerja yang sama \\
6 & Menggunakan peralatan kerja yang sama \\
7 & Adanya penumpukan hasil produksi \\
8 & Membutuhkan Area Kerja yang Luas \\
\hline
\end{tabular}


Standar penulisan derajat hubungan antar fasilitas dapat dilihat pada Tabel 3.4. Oleh karena itu, diperoleh gambar ARC berdasarkan deskripsi alasan keterkaitan antarfasilitas seperti pada Gambar 3.2.

Tabel 3.4. Standar penulisan derajat hubungan aktivitas

\begin{tabular}{cccc}
\hline $\begin{array}{c}\text { Derajat Nilai } \\
\text { Kedekatan }\end{array}$ & Deskripsi & Kode Garis & Kode Warna \\
\hline A & Mutlak & Garis 4 & Merah \\
E & Sangat penting & Garis 3 & Oranye \\
I & Penting & Garis 2 & Hijau \\
O & Cukup/Biasa & Garis 1 & Biru \\
U & Tidak Penting & Tidak ada & Tidak ada warna \\
X & Tidak dikehendaki & Coklat \\
\hline
\end{tabular}

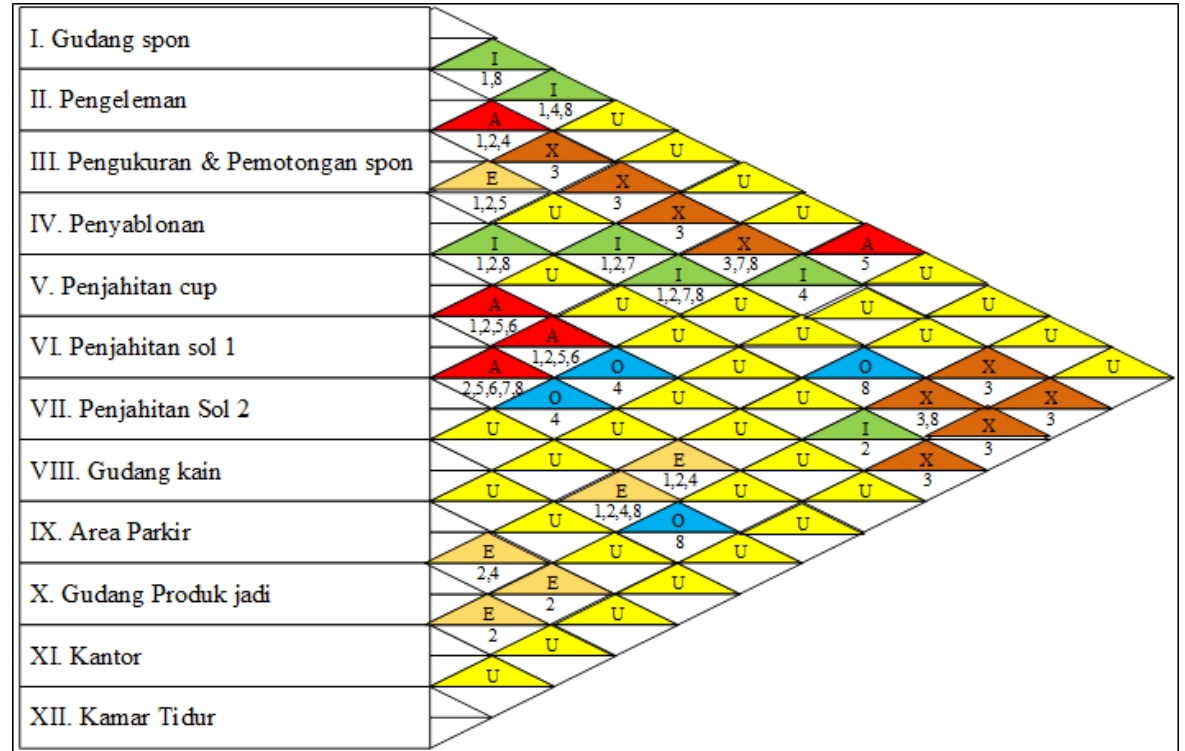

Gambar 3.2. Activity Relationship Chart (ARC)

Selanjutnya, data yang diperoleh dari ARC dimasukan kedalam suatu lembaran kerja (work sheet) derajat kedekatan yang dapat dilihat pada Tabel 3.5.

Tabel 3.5. Lembar kerja (work sheet)

\begin{tabular}{|c|c|c|c|c|c|c|c|}
\hline \multirow[t]{2}{*}{ No } & \multirow{2}{*}{ Fasilitas } & \multicolumn{6}{|c|}{ Derajat Kedekatan } \\
\hline & & $\mathbf{A}$ & E & I & 0 & $\mathbf{U}$ & $\mathbf{X}$ \\
\hline $\mathrm{I}$ & Gudang Spon & 8 & - & 2,3 & - & $4,5,6,7,9,10,11,12$ & - \\
\hline II & Pengeleman & 3 & - & 1,8 & - & 9,10 & $4,5,6,7,11,12$ \\
\hline III & $\begin{array}{l}\text { Pengukuran \& } \\
\text { Pemotongan } \\
\text { Spon }\end{array}$ & 2 & 4 & $\begin{array}{c}1,6 \\
7\end{array}$ & 10 & $5,8,9$ & 11,12 \\
\hline IV & Penyablonan & - & 3 & 5,11 & - & $6,7,8,9,10$ & 2,12 \\
\hline V & Penjahitan Cup & $\begin{array}{l}6, \\
7\end{array}$ & - & 4 & 8 & $1,3,9,10,11,12$ & 2 \\
\hline $\mathrm{VI}$ & Penjahitan Sol 1 & $\begin{array}{l}5, \\
7\end{array}$ & 10 & 3 & 8 & $1,4,8,9,11,12$ & 2 \\
\hline VII & Penjahitan Sol 2 & $\begin{array}{l}5 \\
6\end{array}$ & 10 & 3 & 11 & $1,4,8,9,12$ & 2 \\
\hline VIII & Gudang Kain & 1 & - & 2 & $\begin{array}{c}5, \\
6\end{array}$ & $\begin{array}{c}3,4,5,6,7,9,10,11,1 \\
2\end{array}$ & - \\
\hline IX & Area Parkir & - & 10,11 & - & - & $1,2,3,4,5,6,7,8,12$ & - \\
\hline
\end{tabular}




\begin{tabular}{|c|c|c|c|c|c|c|c|}
\hline \multirow[t]{2}{*}{ No } & \multirow{2}{*}{ Fasilitas } & \multicolumn{6}{|c|}{ Derajat Kedekatan } \\
\hline & & $\mathbf{A}$ & $E$ & I & 0 & $\mathbf{U}$ & $\mathbf{X}$ \\
\hline$x$ & $\begin{array}{l}\text { Gudang Produk } \\
\text { Jadi }\end{array}$ & - & $\begin{array}{c}6,7,9,1 \\
1\end{array}$ & - & 3 & $1,2,4,5,8,12$ & - \\
\hline$X I$ & Kantor & - & 9,10 & 4 & - & $1,5,6,8,12$ & 2,3 \\
\hline XII & Kamar Tidur & - & - & - & - & $1,5,6,7,8,9,10,11$ & $2,3,4$ \\
\hline
\end{tabular}

Dan untuk mempermudah dalam analisis hubungan kedekatan disajikan dalam gambar ARD (activity relationship diagram) seperti pada Gambar 3.3.

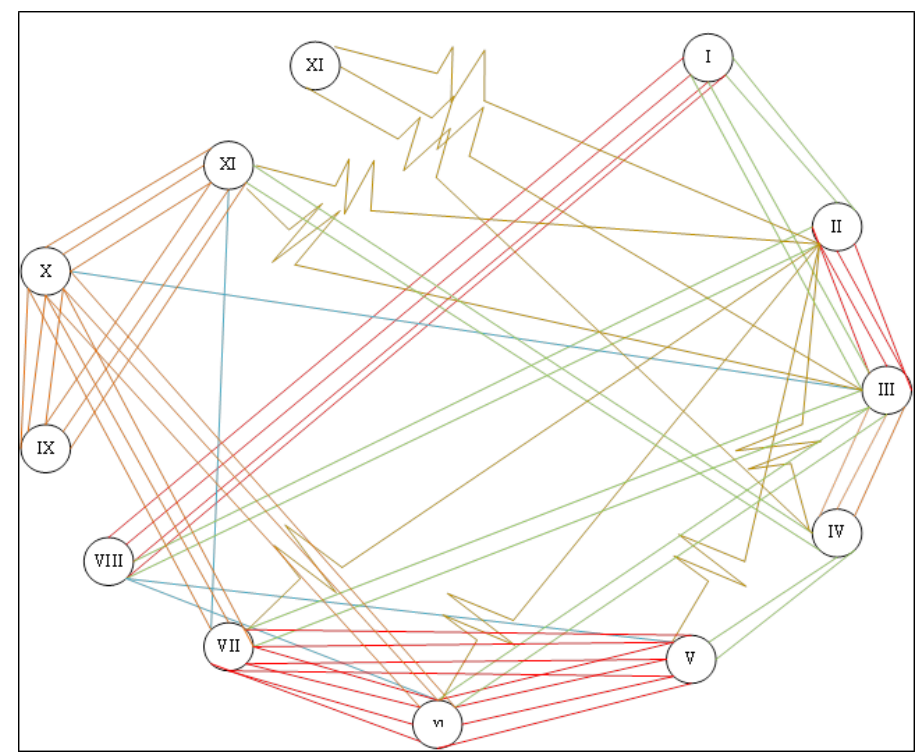

Gambar 3.3. Activity Relationship Diagram (ARD)

\subsection{Perhitungan Total Closeness Rating (TCR)}

Dalam metode CORELAP, pengalokasian tata letak usulan mengacu sepenuhnya pada nilai TCR yang telah didapatkan dari konversi nilai derajat kedekatan yang telah didefinisikan melalui ARC. Perhitungan nilai TCR dapat dilihat pada Tabel 3.6.

Tabel 3.6. Total Closeness Rating (TCR) keseluruhan

\begin{tabular}{|c|c|c|c|c|c|c|c|c|c|c|c|c|c|c|c|c|c|c|c|c|}
\hline \multirow[b]{2}{*}{ Fasilitas } & \multicolumn{12}{|c|}{ Fasilitas } & A & $E$ & 1 & $\mathrm{O}$ & $U$ & $x$ & \multirow[b]{2}{*}{ TCR } & \multirow[b]{2}{*}{$\begin{array}{c}\text { Placement } \\
\text { squence }\end{array}$} \\
\hline & 1 & II & III & IV & V & VI & VII & VIII & IX & $x$ & $\mathrm{XI}$ & XII & 4 & 3 & 2 & 1 & 0 & -1 & & \\
\hline I & & 1 & 1 & $U$ & $U$ & $U$ & $U$ & $A$ & $U$ & $\mathrm{U}$ & $U$ & $U$ & 1 & 0 & 2 & 0 & 8 & 0 & 8 & 6 \\
\hline II & 1 & & $\bar{A}$ & $\mathrm{X}$ & $x$ & $\mathrm{X}$ & $\bar{x}$ & 1 & $U$ & $\mathrm{U}$ & $x$ & $x$ & 1 & 0 & 2 & 0 & 2 & 6 & 2 & 11 \\
\hline III & $\mathrm{I}$ & $A$ & & $E$ & $U$ & $\mathrm{I}$ & $\mathrm{I}$ & $U$ & $U$ & 0 & $x$ & $x$ & 1 & 1 & 3 & 1 & 3 & 2 & 12 & 4 \\
\hline IV & $U$ & $\mathrm{x}$ & $E$ & & 1 & $U$ & $U$ & $U$ & $U$ & $\mathrm{U}$ & $\mathrm{I}$ & $x$ & 0 & 1 & 2 & 0 & 6 & 2 & 5 & 9 \\
\hline $\mathrm{V}$ & $\mathrm{U}$ & $\mathrm{x}$ & $\mathrm{U}$ & 1 & & $A$ & $A$ & 0 & $U$ & $\mathrm{U}$ & $U$ & $U$ & 2 & 0 & 1 & 1 & 6 & 1 & 10 & 5 \\
\hline VI & $U$ & $\mathrm{x}$ & 1 & $U$ & A & & $A$ & 0 & $U$ & $E$ & $U$ & $U$ & 2 & 1 & 1 & 1 & 5 & 1 & 13 & 2 \\
\hline VII & $U$ & $\mathrm{X}$ & $I$ & $\mathrm{U}$ & $\mathrm{A}$ & $A$ & & $U$ & $U$ & $E$ & 0 & $U$ & 2 & 1 & 1 & 1 & 5 & 1 & 13 & 1 \\
\hline VIII & $A$ & 1 & $U$ & $\mathrm{U}$ & 0 & 0 & $U$ & & $U$ & $\mathrm{U}$ & $\mathrm{U}$ & $U$ & 1 & 0 & 1 & 2 & 7 & 0 & 8 & 7 \\
\hline IX & $\mathrm{U}$ & $\mathrm{Uu}$ & $\mathrm{U}$ & $\mathrm{U}$ & $\mathrm{U}$ & $U$ & $U$ & $\mathrm{U}$ & & $E$ & $E$ & $U$ & 0 & 2 & 0 & 0 & 9 & 1 & 5 & 10 \\
\hline$x$ & $U$ & $\mathrm{U}$ & 0 & $\mathrm{U}$ & $\mathrm{U}$ & $\mathrm{E}$ & $E$ & $U$ & $E$ & & $E$ & $U$ & 0 & 4 & 0 & 1 & 6 & 0 & 13 & 3 \\
\hline$\overline{X I}$ & $\mathrm{U}$ & $\mathrm{x}$ & $x$ & 1 & $\mathrm{Uu}$ & $\mathrm{U}$ & I & $U$ & $E$ & $E$ & & $U$ & 0 & 2 & 2 & 0 & 5 & 2 & 8 & 8 \\
\hline XII & $U$ & $\mathrm{x}$ & $x$ & $\mathrm{X}$ & $\mathrm{U}$ & $\mathrm{U}$ & $U$ & $U$ & $U$ & $\mathrm{U}$ & $\mathrm{U}$ & & 0 & 0 & 0 & 0 & 8 & 3 & -3 & 12 \\
\hline
\end{tabular}


Tahap selanjutnya yaitu dilakukan penentuan urutan pengalokasian fasilitas pada layout baru. Penentuan pengalokasian fasilitas pertama didapat dengan melihat nilai TCR tertinggi. Setelah itu, dari fasilitas yang akan dialokasikan, diperoleh nilai derajat kedekatan tertinggi dari fasilitas yang telah dialokasian. Berdasarkan masukan dari pemilik usaha bahwa layout yang baru diharapkan tidak mengubah posisi kantor, area parkir dan kamar sehingga dua fasilitas ini dikeluarkan. Diperoleh pengurutan fasilitas baru adalah 3-6-7-5-1-8-9-2 seperti pada Tabel 3.7.

Tabel 3.7. Total Closeness Rating (TCR) perbaikan

\begin{tabular}{|c|c|c|c|c|c|c|c|c|c|c|c|c|c|c|c|c|}
\hline \multirow{2}{*}{ Fasilitas } & \multicolumn{9}{|c|}{ Fasilitas } & $A$ & $E$ & & 0 & $U>$ & \multirow{2}{*}{ TCR } & \multirow{2}{*}{$\begin{array}{c}\text { Placement } \\
\text { squence }\end{array}$} \\
\hline & I & \begin{tabular}{|l|l|}
11 & I \\
\end{tabular} & III & $\mathrm{IV}$ & $\mathrm{V}$ & JI & VII & VIII & $x$ & 4 & 3 & 2 & 1 & \begin{tabular}{l|l}
0 & -
\end{tabular} & & \\
\hline I & & I & I & $U$ & $U$ & $U$ & $U$ & A & $U$ & 1 & 0 & 2 & 0 & 80 & 8 & 5 \\
\hline II & I & & $A$ & $\mathrm{X}$ & $\mathrm{X}$ & $\bar{x}$ & $x$ & 1 & $U$ & 1 & 0 & 2 & 0 & 2 & 4 & 9 \\
\hline IIII & I & $A$ & & $E$ & $U$ & I & I & U & 0 & 1 & 1 & 3 & 1 & 30 & 14 & 1 \\
\hline IV & U & $\mathrm{x}$ & $E$ & & I & U & U & U & U & 0 & 1 & 2 & 0 & 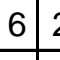 & 5 & 8 \\
\hline V & U & $\mathrm{x}$ & $U$ & I & . & $A$ & $A$ & 0 & U & 2 & 0 & 1 & 1 & \begin{tabular}{l|l}
6 & 1 \\
\end{tabular} & 10 & 4 \\
\hline VI & U & $\mathrm{x}$ & 1 & $\mathrm{U}$ & A & & A & 0 & $E$ & 2 & 1 & 1 & 1 & 5 & 13 & 2 \\
\hline VII & U & $\mathrm{x}$ & 1 & $U$ & A & A & & $U$ & $E$ & 2 & 1 & 1 & 0 & 2 & 12 & 3 \\
\hline VIII & $\mathrm{A}$ & 1 & $\mathrm{U}$ & $U$ & O & 을 & U & & $U$ & 1 & 0 & 1 & 2 & \begin{tabular}{|l|l}
7 & \\
\end{tabular} & 8 & 6 \\
\hline$x$ & U & $\mathrm{U}$ & 0 & $U$ & $U$ & $\mathrm{E}$ & $E$ & $U$ & & 0 & 2 & 0 & 1 & \begin{tabular}{|l|l|}
5 & 1 \\
\end{tabular} & 7 & 7 \\
\hline
\end{tabular}

Proses pembuatan layout baru dengan menggunakan metode CORELAP juga mempertimbangkan nilai unit' square dari setiap fasilitas seperti pada Tabel 3.8.

Tabel 3.8. Nilai Unit Square's

\begin{tabular}{ccc}
\hline Fasilitas & sq.ft & $\begin{array}{c}\text { Num Of } \\
\text { Gris }\end{array}$ \\
\hline I & 4.14 & 5 \\
II & 3.99 & 4 \\
III & 6.42 & 7 \\
IV & 1.25 & 2 \\
V & 0.64 & 1 \\
VI & 0.76 & 1 \\
VII & 4.53 & 5 \\
VIII & 2.31 & 3 \\
X & 0.06 & 1 \\
\hline
\end{tabular}

\subsection{Pengalokasian usulan layout-layout alternatif}

Pembuatan alternatif layout nantinya mengacu pada nilai placement sequence pada tabel dan nilai Unit Square's Departemen pada tabel serta mempertimbangkan urutan prosesnya. Adapun penyusunannya dilakukan dengan Activity Template Block Diagram (ATBD) dengan melakukan beberapa iterasi untuk memperoleh nilai score terendah seperti pada Gambar 3.4, Gambar 3.5, Gambar 3.6, Gambar 3.7, dan Gambar 3.8. 


\begin{tabular}{|l|l|l|l|l|}
\hline & & 7 & & \\
\hline 3 & 3 & 7 & & \\
\hline 3 & 3 & 7 & & \\
3 & 3 & 7 & 4 & 4 \\
3 & 6 & 7 & 9 & 2 \\
1 & 1 & 5 & 8 & 2 \\
1 & 1 & 8 & 8 & 2 \\
\hline & & & & 2 \\
\hline
\end{tabular}

ALTERNATIF 1

\begin{tabular}{|c|c|}
\hline Hubungan Antar Fasilitas & nilai score \\
\hline Fasilitas3 dan 2 & 2 \\
\hline Fasilitas4 & 6 \\
\hline Fasilitas1 & 4 \\
\hline Fasilitas 7 & 2 \\
\hline Fasilitas 5 & 5 \\
\hline Fasilitas8 & 3 \\
\hline Fasilitas9 & 0 \\
\hline Fasilitas6 & 1 \\
\hline Jumlah & $\mathbf{2 3}$ \\
\hline
\end{tabular}

Gambar 3.4. Alternative 1

\begin{tabular}{|c|c|c|c|c|c|c|c|}
\hline & & & & & & \multicolumn{2}{|c|}{ ALTERNATIF 2} \\
\hline & & & & & & Hubungan Antar Fasilitas & nilai score \\
\hline & & & & & & Fasilitas3 dan 2 & 2 \\
\hline & & \multirow{2}{*}{7} & \multicolumn{2}{|r|}{1} & 1 & Fasilitas 4 & 6 \\
\hline & \multirow{3}{*}{7} & & \multirow{2}{*}{3} & 1 & 1 & Fasilitas1 & 4 \\
\hline \multirow{6}{*}{9} & & 7 & & 3 & 8 & Fasilitas 7 & 2 \\
\hline & & . & 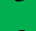 & & 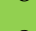 & Fasilitas 5 & 6 \\
\hline & 7 & 7 & 3 & 3 & 8 & Fasilitas8 & 3 \\
\hline & 5 & 6 & 3 & 3 & 8 & Fasilitas9 & 3 \\
\hline & & 4 & 2 & 2 & & Fasilitas 6 & 3 \\
\hline & & 4 & 2 & 2 & & Jumlah & 29 \\
\hline
\end{tabular}

Gambar 3.5. Alternative 2

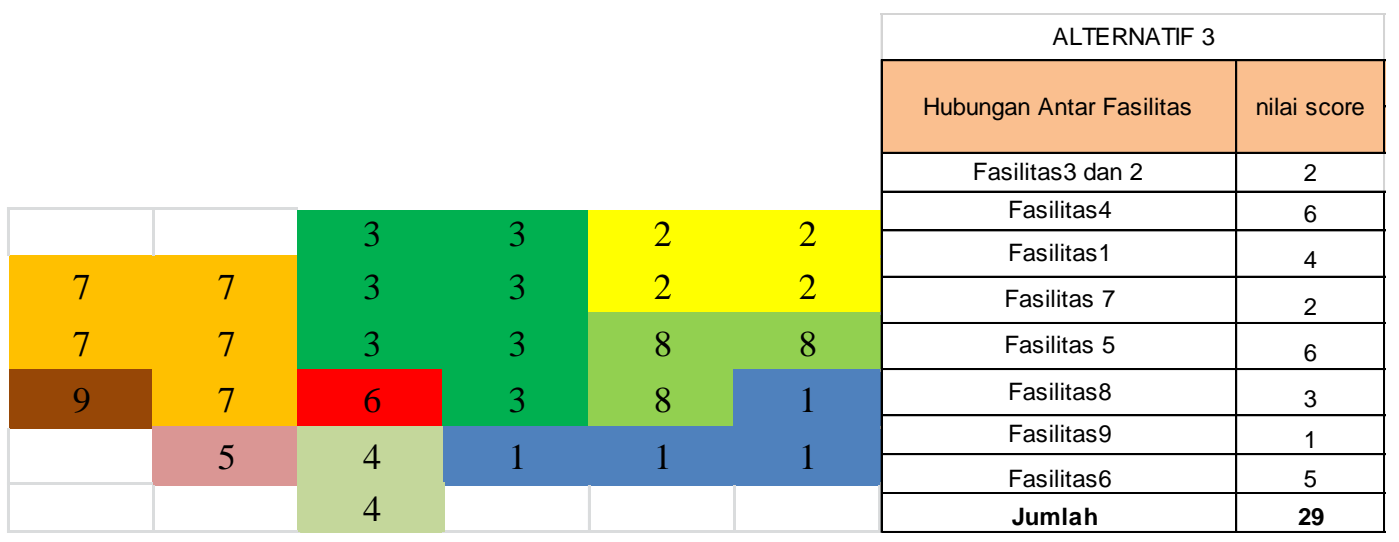

Gambar 3.6. Alternative 3 


\begin{tabular}{|c|c|c|c|c|c|c|}
\hline & & & & & \multicolumn{2}{|c|}{ ALTERNATIF 4} \\
\hline & & & & & Hubungan Antar Fasilitas & nilai score \\
\hline & & & & & Fasilitas3 dan 2 & 2 \\
\hline & 7 & 8 & 8 & 2 & Fasilitas 4 & 4 \\
\hline 7 & 7 & 1 & 8 & 2 & Fasilitas1 & 4 \\
\hline 7 & 7 & 1 & 1 & 2 & Fasilitas 7 & 2 \\
\hline 9 & 6 & 3 & 1 & 2 & Fasilitas 5 & 4 \\
\hline 4 & 5 & 3 & 3 & & Fasilitas8 & 6 \\
\hline \multirow{3}{*}{4} & & \multirow{2}{*}{3} & \multirow{2}{*}{3} & & Fasilitas9 & 2 \\
\hline & & & & & Fasilitas6 & 4 \\
\hline & & 3 & 3 & & Jumlah & 28 \\
\hline
\end{tabular}

Gambar 3.7. Alternative 4

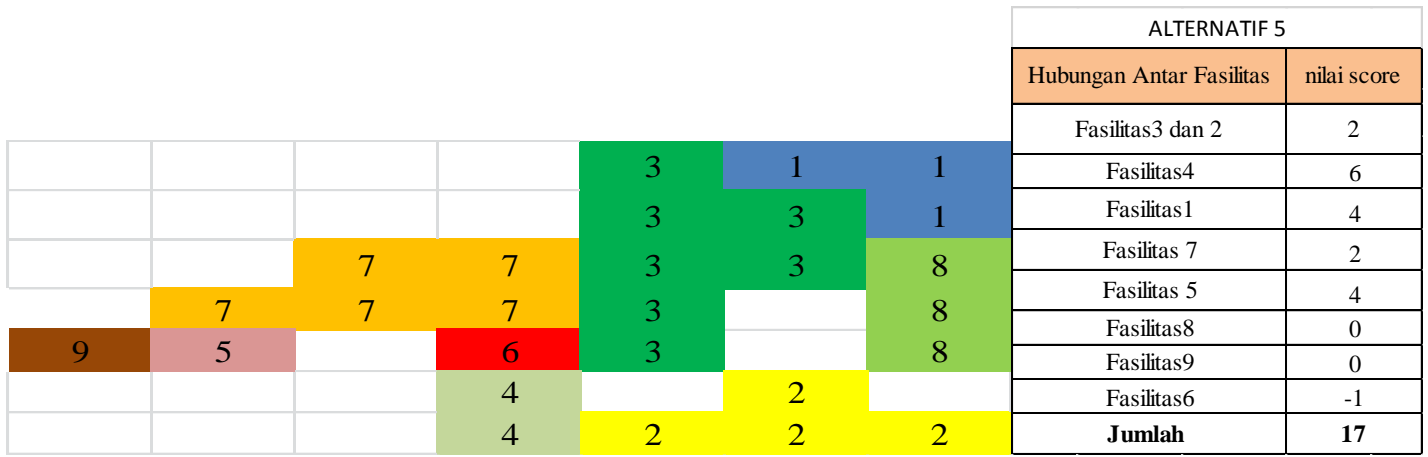

Gambar 3.8. Alternative 5

Berdasarkan 5 alternatif, diperoleh layout alternative ke-5 yang memiliki score 17 sehingga terpilih menjadi layout terbaik karena skor terendah menunjukkan jarak tempuh yang terendah juga sehingga gambar aliran proses dapat dilihat seperti pada Gambar 3.9.

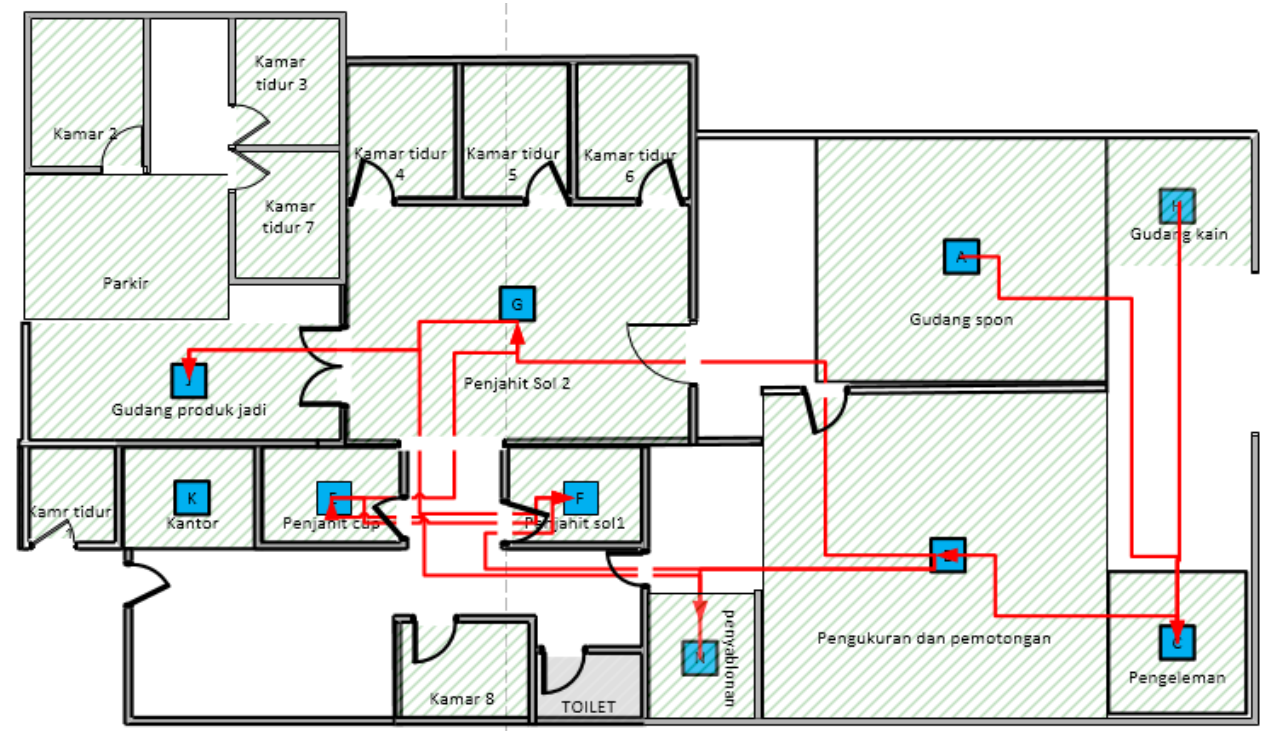

Gambar 3.9. Aliran proses dari Alternatif Terbaik 
Total jarak tempuh dalam satu proses pembuatan sandal dapat dilihat pada Tabel 3.9 yaitu sebesar $125.8 \mathrm{~m}$. Total jarak tempuh ini mengalami penurunan sebesar $46 \%$ dari total jarak tempuh awal sebesar $273.5 \mathrm{~m}$.

Table 3.9. Aliran proses Alternatif Terbaik

\begin{tabular}{cccc}
\hline From & To & $\begin{array}{c}\text { Jarak } \\
(\mathbf{m})\end{array}$ & $\begin{array}{c}\text { Total Jarak } \\
(\mathbf{m})\end{array}$ \\
\hline A & B & 12.9 & \\
A & C & 6.2 & \\
H & B & 23.20 & \\
B & C & 7.1 & \\
C & D & 7.2 & \\
C & $F$ & 9.00 & 125.8 \\
C & G & 14.65 & \\
D & E & 12.65 & \\
E & F & 5.65 & \\
E & G & 7.6 & \\
F & J & 11.3 & \\
G & J & 8.35 & \\
\hline
\end{tabular}

\section{Kesimpulan}

Penelitian ini bertujuan merancang ulang ulang tata letak fasilitas perusahaan sandal untuk mendapatkan layout dengan jarak yang lebih pendek. Layout awal mempunyai total luasan sebesar $249,38 \mathrm{~m}^{2}$ dengan total jarak material handling sebesar $273,5 \mathrm{~m}$. Setelah dilakukan analisis untuk perancangan ulang dengan metode CORELAP diperoleh jarak total sebesar 125,8 dengan beberapa perubahan yang dilakukan. Gudang spon dan gudang kain berpindah ke area belakang karena harus berdekatan dengan bagian pengukuran dan pemotongan bahan, bagian pengukuran dan pemotongan bahan bertukar posisi dengan bagian pengeleman untuk mengurangi gangguan kerja akibat proses penyemprotan latex. Area penyablonan bergeser untuk pembuatan akses jalan, area penjahitan cup dan penjahitan sol 1 harus didekatkan dengan bagian penjahitan sol 2, dan area kamar menjadi 1 wilayah berdekatan dengan area parkir sehingga mempermudah beraktivitas. Oleh karena itu, terjadi penghematan jarak perpindahan material sebesar $46 \%$.

\section{Daftar Pustaka}

[1] S. Wignjosoebroto, "Tata Letak Pabrik Dan Pemindahan Bahan; edisi ke-3," Guna Widya, Surabaya, 2009.

[2] M. Faishal and M. A. Pratama, "Perancangan ulang tata letak fasilitas perusahaan sandal hotel dengan metode ARC untuk mengurangi waste," Jurnal Teknologi, vol. 12, no. 2, pp. 116-122, 2019.

[3] P. A. Budiono, "Penyusunan tata letak stasiun kerja restoran " $X$ " menggunakan metode algoritma CORELAP," Penerbit MMT ITS, Surabaya, 2006.

[4] Q. A. Dwianto, S. Susanty, and L. Fitria, "Usulan rancangan tata letak fasilitas dengan menggunakan metode Computerized Relationship Layout Planning (CORELAP) di perusahaan konveksi," Reka Integr., vol. 04, no. 01, pp. 87-97, 2016.

[5] D. Langgihadi, A. Bakar, and S. Susanty, "Usulan rancangan ulang tata letak fasilitas dengan Menggunakan Metode Computerized Relationship Layout Planning (CORELAP) di perusahaan distribusi bahan bakar pesawat udara," Reka Integr., vol. 4, no. 1, p. 275-286, 2016.

[6] M. Faishal, A. Saptari, and H. M. Asih, "Relayout planning to reduce waste in food industry through simulation approach," in Asian Simulation Conference, pp. 496-508, 2017.

[7] A. A. A. Wibawanto, M. Choiri, and A. Eunike, "Perancangan tata letak fasilitas produksi pestisida II dengan metode Computerized Relationship Layout Planning (CORELAP) untuk meminimasi material handling (studi kasus: PT. Petrokimia Kayaku Gresik)," J. Rekayasa dan Manaj. Sist. Ind., vol. 2, no. 4, pp. 871-883, 2014. 
[8] P. W. J and E. Shayan, "Layout design of a furniture production line using formal methods," J. Ind. Syst. Eng., vol. 1, no. 1, pp. 81-96, 2007.

[9] Y. P. Putra, "Merancang tata letak fasilitas pabrik dengan metode algoritma CORELAP di CV. Robbani Singosari," J. Valtech, vol. 1, no. 1, pp. 65-70, 2018.

[10] R. M. Siregar, D. Sukatendel, and U. Tarigan, "Perancangan ulang tataletak fasilitas produksi dengan menerapkan algoritma Blocplan dan algoritma Corelap pada PT. Xyz," J. Tek. Ind. USU, vol. 1, no. 1, pp. 35-44, 2013.

[11] N. H. Prasad, G. Rajyalakshmi, and a. S. Reddy, "A typical manufacturing plant layout design using CRAFT algorithm," Procedia Eng., vol. 97, pp. 1808-1814, 2014.

[12] C. N. Rubianto and L. Y. Bendatu, "Penentuan lokasi dan perancangan tata letak fasilitas tempat packaging PT. ABC," J. Titra, vol. 2, no. 2, pp. 65-70, 2014. 